\title{
Implementing Joyful learning Strategy Using Treasure Clue Game Method in Order to Improve Reading Comprehension Skill
}

\author{
Vina Anggia Nastitie Ariawan ${ }^{1}$ *, Inne Marthyane Pratiwi ${ }^{1}$ \\ ${ }^{1}$ Department of Primary Education, Universitas Pendidikan Indonesia. Jl. Dr. Setiabudhi No. 229 \\ Bandung 40154 Jawa Barat, Indonesia \\ * Corresponding Author. Email: vivianatsir@gmail.com \\ Received: 7 November 2016; Revised: 5 June 2017; Accepted: 6 June 2017
}

\begin{abstract}
The objectives of the study were: (1) to describ steps in implementing the joyful learning strategy using treasure clue game method in order to improve reading comprehension skill for the rade 4 students of elementary school; and (2) to improve-reading comprehension skill for the grade 4 students of elementary school by implementing the joyful learning strategy through treasure clue game method. The study was a collaborative Class Action Research (CAR) and was conducted in two cycles. Each cycle consisted of two meetings. The study took place in one of the elementary schools in Kuningan. The subjects in this study were 31 grade 4 students of an elementary school. In collecting the data, the researchers performed observation, interview, and data analysis. The data were analyzed using thematic analysis and were validated using triangulation, member checking, and reflection. The results of the study showed that the joyful learning strategy using treasure clue game method could increase the students' reading comprehension skill. These results have been proven by the increase on the students' reading comprehension outcome in each cycle. The students' passing grade percentage in the first cycle is $73.86 \%$, while that in the second cycle is $87.56 \%$. Therefore, the students' learning outcomes has passed the performance indicator in this study, namely $85.00 \%$. At the end, the researchers conclude that the implementation of joyful learning strategy using treasure clue game method can improve grade 4 students' reading comprehension skill.
\end{abstract}

Keyword: joyful learning, treasure clue, reading comprehension

How to Cite: Ariawan, V., \& Pratiwi, I. (2017). Joyful learning strategy using game method of treasure clue to improve reading comprehension skill. Jurnal Prima Edukasia, 5(2), 203-210. doi:http://dx.doi.org/10.21831/jpe.v5i2.11601

Permalink/DOI: http://dx.doi.org/10.21831/jpe.v5i2.11601

\section{Introduction}

Reading comprehension is a type of reading activity that urges students to understand reading materials that involves appropriate association between word meaning and word symbol, assessment of meaning context that has been assumed to present, selection of appropriate words, organization of ideas when the learning materials are read, idea storage, and the use of idea storage in multiple activities both in the present and the future times (Ahuja \& Ahuja, 2010). Reading comprehension is an advanced stage where students understand the content of reading materials, select the reading materials that will be implemented in their life, and develop curiosity and critical thinking in their personality (Ortlieb, 2013).
Reading comprehension is very important to be mastered by students so that they can understand the matters that they read and they can implement these matters into the daily life (Lan, Lo, \& Hsu, 2014). However, in the present time it has been found that many students display lack of interest toward reading activities especially the ones related to reading comprehension. As a result, the students' reading habit, critical thinking, and creative thinking might decrease and the students' literary culture might disappear (Zare \& Othman, 2013).

In relation to the above explanation, this study is encouraged by a previous study by Linane (2014), who studied the factors of low reading comprehension skill in Mattapoiset elementary schools, Massachussets. Linane 
(2014) wrote questions for teachers' guidelines in order to identify the factors that caused the low students' reading comprehension in elementary schools.

Linane (2014) found at least six causes of the students' low interest in performing reading comprehension skill and the causes are as follows: (1) the use of discourse language that is too complicated; (2) the discourse topics that is not in line with the students' characteristics; (3) the discourse text that is too long; (4) the evaluation test items that is not in line with the discourse or that is not related to the discourse; (5) the teachers' low capability in providing feedback for the students so that there is a misunderstanding between the teachers and the students; and (6) the learning presentation that only emphasizes on the concept of reading text and answering questions.

The causes of students' low reading comprehension skill in Massachussets are almost similar to those in Indonesia. This is in line with an opinion by Rofikasari (2016), who stated that the low students' reading comprehension skill has been caused by the lack of innovative reading comprehension learning and the less interesting reading materials for the students.

The low students' reading comprehension skill might be overcome through the implementation of multiple learning strategies. One of the strategies that might be implemented by the teacher in the learning is joyful learning. Joyful learning is a learning process that involves students so that they will feel happy, interested, and comfortable in attending the learning process (Proity, 2015).

Joyful learning puts students as the leading character in the learning process and teachers as the facilitator. Joyful learning might improve students' imaginative capability, trigger learning enthusiasm, and motivate students to keep learning (Kohn, 2010; Shirah, 2006).

Through joyful learning, holistic learning might be implemented naturally because the students' emotion, socialism, and cognition will indirectly be integrated and be apparent in the learning. Therefore, a teacher should create a joyful situation within the learning in order to trigger the students' learning enthusiasm. In joyful learning, each teacher is free to implement any learning designs that support the joyful concept (Wei, Lee, \& Chen, 2011). One of the learning methods that might be imple- mented in the joyful learning strategy is the game method.

The method game that might be implemented as an effort to improve the students' reading comprehension skill is treasure clue. Treasure clue is a simple game that can be played in groups and in this game students should find treasure by guessing te clues that have been provided (Nurlina et al., 2013).

Understanding and speed are two keys to success in the treasure clue game. The steps in playing the treasure game clue are as follows: (1) teachers divide students in several groups; (2) each group is provided with several cards containing clues; (3) each group should guess the clues in a sequence according to the number in each clue; (4) each group explains the answer of the clue in front of the class; and (5) the fastest group that fins the treasure will be the winner of the game (Nurlina et al., 2013).

In the treasure clue game, students will have directions that they should understand in order to continue their mission of finding the treasure. Teacher presents the directions by using the language that students will easily understand while encourage them to accomplish the mission enthusiastically. Through the joyful learning strategy in the form of treasure clue game method, it is expected that students will be motivated to learn so that they can improve their reading comprehension skill.

The joyful learning strategy has been implemented by previous study in order to improve the English reading comprehensio0n skill. This study was conducted by (Jadal MM, 2012) in Indian elementary schools. The results of his study showed that the joyful learning strategy has had significant influence on elementary school students' reading comprehension skill.

Based on the results of previous study by (Jadal MM, 2012), the researchers would like to conduct an action class research in order to improve Grade 4 students' reading comprehension skill through treasure clue game method.

\section{Method}

This study made use of qualitative research with Kemmis and MC Taggart modelbased class action research design. The Kemmis and MC Taggart model consisted of four components namely planning, implementation, observation, and reflection (Arikunto, Suhardjono, \& Supardi, 2010). The type of class 
action research that had been implemented was collaborative class action.

Class action research was a form of reflection that had been conducted in order to overcome learning problems within classrooms through individual or collaborative actions (Cohen, Manion, \& Morrison, 2007).

The study was conducted in one of the elementary schools in the Sub-Regency of Kuningan, Regency of Kuningan. The study took place on September 2016. The participants in this study were 31 Grade 4 students from 2016/2017 Academic Year. On the other hand, the other participants were Grade IV teachers who served as collaborators from the elementary school.

In conducting this study, the researchers made use of several data gathering techniques namely observation, interview, and document analysis. Observation was a data gathering technique that observed and took notes on every phenomenon with regards to the matters under study through certain tools (Sanjaya, 2016). The observation that the researchers conducted was elaborated in the form of field notes so that every phenomenon might be recalled well by the researchers and the researchers might avoid phenomenon manipulation. The researchers in this study, therefore, served as the observers without getting involved directly into the participants' activities.

Cohen et al. (2007) revealed that observation assisted researchers to see factually the phenomena in the field, to open their mind, to find unrevealed matters that participants had during interviews, and to access personal understanding.

The next data gathering technique that the researchers implemented was interview. Interview was a data gathering technique that had been useful for collecting in-depth information regarding the implementation of joyful learning strategy using treasure clue game method among the Grade 4 students (Putra \& Dwilestari, 2012). The interview was conducted informally through open questions; in the interview, the researchers took notes on the participants' answers.

The sources in this interview were Grade 4 teachers and students. The interview was conducted informally through open questions and the researchers took notes on the participants' answers. Informal interview was an interview that had been commonly conducted as daily conversation in relax and fluent situation under scientific context (Putra \& Dwilestari,
2012). The informal interview was selected in order that the teachers and the students would like to share their experiences or difficulties comfortably without any pressure.

Meanwhile, document analysis was an activity of analyzing learning results that the students had attained through the implementation of joyful learning strategy using treasure clue game method. The document served as complimentary and enriching source for the information that had been attained from the interview and the observation (Alwasilah, 2002). Through the document, the researchers might see the concrete evidence on the students' reading comprehension skill. The indicator of performance achievement in this study was 85.00\%; this indicator implied that the students who completed the learning process were $85.00 \%$.

For the data analysis in this study, the researchers made use of thematic analysis technique. MacNaughton \& Hughes (2009) stated that thematic analysis was a data analysis technique that had been conducted by viewing and looking for the themes and categories that had been attained in the data that had been encoded first. The stages of data analysis in this technique were: (1) preparing the raw data; (2) reading the overall data; (3) coding the data; (4) associating the coding results; and (5) interpreting the coding results (Creswell, 2016).

Validity and reliability referred to the data quality problems and the accuracy of the method that had been implemented in conducting a study. Validity had been an effort of checking the accuracy of the study results by applying certain procedures (Neuman, 2014). On the other hand, reliability indicated that the approach that a researcher had implemented would be consistent for different researchers and different projects (Creswell, 2014).

The researchers made use of triangulation, member checking, and reflection as the form of data validity test. Triangulation was a process of benefitting various perceptions for clarifying meaning, verifying the possibility of repetition in an observation, or for performing interpretation under a principle that an observation or interpretation should not be repeated (Denzin \& Lincoln, 2011).

Triangulation referred to gathering as much information as possible from various sources through various methods (Cohen et al., 2007). This study made use of triangulation toward the data that had been attained from the 
field notes, the interview results, and the document analysis. In addition, the researchers also attained the data from various sources namely Grade 4 teachers and students.

Member checking was a technique for testing the data validity and the researchers performed the data checking in order to: (1) avoid misinterpreting the respondents' answers during the interview; (2) avoid misinterpreting the respondents' behaviors during the interview; and (3) confirm the respondents' perspective toward a process that had been occurring (Alwasilah, 2002).

Reflection referred to the researchers' awareness in putting themselves into their report; here, the researchers should be aware of bias, value, and experiences that they brought about (Creswell, 2012).

It was important for the teachers to not only explaining their experiences with the phenomena under study but also realizing that these experiences might heavily influence their findings, their conclusions, and their interpretations in this study. The researchers should maintain their attitudes, display friendliness, and try to be invisible in the classroom so that the learning would occur naturally. The researchers should not interfere and force the participants to do the activities that the researchers demanded.

\section{Results and Discussions}

Cycle 1 Meeting 1

Cycle 1 Meeting 1 was conducted on Thursday, September $8^{\text {th }}, 2016$. The learning materials for this meeting were composing directions based on maps. The number of students who attended the first meeting was 29 students and two students were absent.

The treasure clue learning in the first meeting was conducted inside the classroom so that the students would have good conditions for performing the treasure clue experiment. The joyful learning strategy using treasure clue game method was not well implemented. The teacher had explained the rules of the game and had provided directions in front of the students. However, during the treasure clue game most of the groups did not understand the directions appropriately.

The students assumed that this game might be played individually whereas in the rules of the games it had been stated that the game should be played in groups. In the first meeting, the treasure clue game had not achieved the expected results. The students' misunderstanding took away most of the learning time; as a result, the learning evaluation was conducted in a hurry.

Although most of the students had not understood the treasure clue game, there were two groups that had been able to play the game well. These groups solved the clue cooperatively and they were able to accomplish the assigned missions. At the end of the learning, the teacher explained once again the game that the students had played. The teacher also provided opportunities for the groups who had accomplished the mission to share their opinions about the treasure clue game.

"The game was fun, Ma'am. We would like to have some sort of this learning again. We could accomplish the mission because we followed the directions that had been provided together." (Interview on September $8^{\text {th }}, 2016$ )

"My group played the treasure clue game together so we looked for the clues collaboratively. We also measured the steps together; as a result, we did not make any mistakes. If we read and followed the directions then we would be provided with other directions and, therefore, we would find the treasure. This kind of learning is fun, so we would like to have more of it." (Interview on September $8^{\text {th }}, 2016$ )

The students' response toward the treasure clue game was quite positive. The groups that had successfully played the game even looked enthusiastic and they demanded to play the game again. On the other hand, the groups that had not successfully accomplished the mission tried to follow again the directions that had been provided. After they followed the provided directions appropriately, the groups that had not successfully played the game realized that they had not been careful in following the directions.

Due to the fact that there were many students who had not understood the rules of this game, the students' learning results were influenced. In Cycle 1 Meeting 1, the students' average learning results were 70.69 . The number of the students who passed the minimum grade was 19 people or $65.52 \%$. On the other hand, the number of the students who did not pass the minimum grade was 10 people or $34.48 \%$. The number of the students who passed the grade 
had not met the performance achievement indicator namely $85.00 \%$. Based on the students learning results in Cycle 1 Meeting 1, the researchers proceeded to Cycle 1 Meeting 2.

\section{Cycle 1 Meeting 2}

Cycle 2 Meeting 2 was conducted on Friday, September $16^{\text {th }}$ ，2016. The learning materials in Cycle 1 Meeting 2 were composing directions based on maps. The number of students who attended this cycle was 28 people and three students were absent. First, the teacher explained again the cardinal directions and provided an example of how to compose directions based on maps. This was performed in order to equalize the perception between the teacher and the students. The teacher also guided the students to try composing directions based on maps in order that the students understood the materials better.

After the teacher explained the learning materials, he divided the group heterogeneously. After the teacher gave his instruction, the students started to work on the quest for their treasure in their groups. Each group seemed to be more cohesive and to have better cooperation in comparison to the previous meeting.

The learning in Cycle 1 Meeting 2 ran better than the one in the previous meeting. The students attended to the learning orderly and enthusiastically. All students took active participation and could follow the directions better. This was proven by the fact that all groups had been able to find their own treasure. The teacher and the students could learn orderly, actively, and joyfully. The teacher interviewed the groups that failed to accomplish their mission last week.

"Now my group is able to read and to follow the direction. This shows our cohesiveness. We truly find our clues one after another. We are so happy to find the clues and to accomplish the mission. Now, we can find the directions inside the classroom. If we play this game outside, then we will have more fun." (Interview on September $16^{\text {th }}$, 2016)

"Yes! We could find our treasure. We have followed your direction so that we did not make any mistake again. It is different because we had mistakes in the previous meeting. The game is challenging and, because of it, we fell happy. Can we enjoy the same learning again? We feel a lot of fun, especially when we play this game outside. We believe we can accomplish the mission." (Interview, September $16^{\text {th }}, 2016$ )

The students' response toward this game was very good; they feel happy because the learning was conducted with game. This proved that the joyful learning strategy using treasure clue game method had been appropriate to implement among the students during their learning. The students did not feel depressed and they seemed to be enthusiastic although they should understand the directions in order to find their treasure.

The students' average learning results in Cycle 1 Meeting 2 were 86.07. The number of students who passed the minimum grade in Cycle 1 Meeting 2 was 23 people or $82.14 \%$, while the number of students who did not pass the minimum grade in this occasion was 5 people or $17.86 \%$. The learning results in Cycle 1 Meeting 2 had good improvement; however, the percentage of the students who passed the minimum grade had not achieved the target in this study. Therefore, the researchers proceeded the study to Cycle II Meeting 1.

\section{Cycle II Meeting 1}

Cycle 2 Meeting 1 was conducted on Thursday, September $22^{\text {nd }}, 2016$. The number of students who attended this meeting was 26 people and 5 students could not attend the learning. The learning materials in the third meeting was completing maps based on the given directions. The treasure game clue in the third meeting was conducted outside the classroom based on the students' request.

The teacher drew the school map and provided reinforcement regarding the cardinal directions in order to achieve equal perception with the students. The teacher also assigned several students to compose directions based on the school map. Next, the teacher divided the students into several heterogeneous groups and distributed the clues to each group. Before starting the game, the teacher explained the directions and the rules of the game that the students should obey. The teacher observed how the students played the treasure clue game outside the classroom. In the same time, the teacher also guided the groups that seemed to be confused in looking for their clues.

Today's learning activities had been well implemented although there were several obstacles that had been found. The reason was 
that the rain had been heavy last night and this caused the clues that had been sticked on the trees to be wet and the writings on the clue to be unclear. These obstacles could be overcome well because the students played the game according to the rules.

The students played the game orderly and actively and yet they were not noisy; as a result, this activity did not disturb the students who studied in their classrooms. The students' response toward the treasure clue game that had been conducted outside the classroom was positive. This was proven by the results of the teacher's interview toward several students with regards to the treasure clue learning.

"It is fun to have this treasure clue learning outside the classroom because the learning activities are conducted around the school. However, some clues were wet so we could not read it. Some other clues fell to the ground and got stepped. Anyway, it is not a big deal because our teacher helps us so that we could find our treasure." (Interview on September 22 $2^{\text {nd }}, 2016$ )

"The game was fun; all group members were cooperating one to another so none of us just stood still and did nothing. All of us were thinking and working our part on this mission. It was fun to play outside the classroom. Unfortunately, the yard was muddy due to the rain last night. We would like to play this game again." (Interview on September $22^{\text {nd }}, 2016$ )

The students' learning results in Cycle 2 Meeting 1 were 90.38. The number of students who passed the minimum grade was 23 people or $88.46 \%$. The number of students who did not passed the minimum grade were 3 people or $11.54 \%$. The students' average learning results and the number of students who passed the minimum grade significantly increased. In addition, the number of students who passed the minimum grade had achieved the target in this study namely $85.00 \%$. Although the number of students who had achieved the target in this study, the researchers proceeded to the following meeting in order to ensure the stagnant or the dynamic increase.

\section{Cycle II Meeting 2}

Cycle 2 Meeting 2 was conducted on Saturday, September $24^{\text {th }}, 2016$. The number of students who attended the third meeting was 30 people and 1 student could not attend the learning. The learning materials for this meeting was completing maps based on the given directions. The teacher distributed a map to each student. Then, the teacher asked the students in order to administer the test of students' preliminary knowledge. After the teacher finished the question and answer session and attained equal perception with the students, he divided the students into several heterogeneous groups.

The treasure clue game in this occasion was also held outside the classroom. The treasure clue game was played better than the one in the previous meeting. In addition, the learning did not encounter any obstacles as well so that the students might carry out the quest for their treasure without any difficulties.

The teacher only observed and reminded the students to return to their class after they found their treasure. The treasure clue game was played without taking too much learning time. The students who played this game orderly would certainly accomplish their mission and would quickly find their treasure so that the remaining time might be used for performing evaluation.

The students' average learning results in Cycle II Meeting 2 were 91.00. The number of students who passed the minimum grade was 26 people or $86.67 \%$. On the other hand, the number of students who did not pass the minimum grade was 4 people or $13.33 \%$. The students who passed the minimum grade in Cycle II Meeting 2 had met the target of performance indicator in this study; therefore, this study is already completed.

\section{Discussions}

The first meeting of joyful learning strategy implementation through treasure clue game method has not been conducted well. The reason is that the students have assumed that the treasure clue game might be performed individually and, as a result, the students are fighting over the clues in order to find the treasure. However, from the second to the last meeting the treasure clue game might be performed well and it is proven by the students' learning results that have improved significantly in each meeting.

The percentage of the students who pass the minimum grade from the first meeting to the fourth meeting respectively is $65.52 \%, 82.14 \%$, $88.46 \%$, and $86.67 \%$. The students' response 
toward the treasure game clue is very positive and it is shown clearly when they play the game actively, jofyully, and orderly. The students' orderliness in playing the treasure clue game has caused the learning to run according to the time allotment. Based on the results of this study, the researchers have found the fact that the students' learning motivation will be triggered if the teacher or the teacher can trigger their spirit.

The students' failure in achieving the learning objectives might be caused by the teacher who has paid less attention toward their learning needs. Elementary school students are the ones who like exploring, who like playing, and who have high curiosity. Therefore, an teacher should carry out his or her responsibilities in meeting their needs by implementing a learning that suits their characteristics.

The joyful learning strategy that has been implemented through the treasure clue game strategy can be an alternative learning that an teacher might implement in the school. The joyful learning strategy is a learning strategy that prioritizes students' involvement in the learning so that they will maintain their learning spirit. Based on the results of this study, the researcher might infer that the joyful learning strategy using treasure clue game method can improve Grade 4 students' reading comprehension skill.

\section{Conclusions}

The joyful learning strategy using treasure clue game method has been one of the innovative learning strategies that will be useful for improving the learning in elementary schools. The steps in implementing the joyful learning strategy using treasure clue game method are as follows: (1) the teacher divides the students into several groups; (2) each group will be provided with several cards that contain clues; (3) each group should guess the clues in order according to the number that has been written in the clues; (4) each group explains the answer of those clues in front of the class; (5) the fastest group that find the treasure will be the group that wins the game. The results of the study from Cycle I to Cycle II are respectively as follows: $65.52 \%$; $82.14 \% ; 88.46 \%$; and $86.76 \%$. These results show that the implementation of joyful learning strategy using treasure clue game method can improve grade 4 students' reading comprehension skill.

A teacher should pay attention to the causes of the students' low reading comprehen- sion skill from various perspectives. A teacher should also perform self-reflection toward all matters that he or she has committed during the learning. The students' failure in understanding the learning is not only caused by their low learning motivation but also by the teaching style that has been selected; in fact, the teaching style might cause the students' greatest failure. The joyful learning might be one of the strategies that a teacher can choose in raising the students' learning motivation. The core of joyful learning strategy is presenting a learning process in a happy and joyful manner so that the students will be happy in the learning process. A teacher can also pour out his or her creativity and innovative thinking in the learning through the use of joyful learning strategy. In addition, while performing the learning process a teacher should select a representative discourse namely the one which contents are in line with the students' characteristics and can encourage the students to keep reading. The reading sources might come not only from textbooks but also from magazines, newspapers, or both teachers' and students' works.

\section{References}

Ahuja, P., \& Ahuja, G. C. (2010). Membaca: Secara efektif dan efisien. Bandung: Kiblat Buku Utama.

Alwasilah, A. C. (2002). Pokoknya kualitatif: Dasar-dasar merancang dan melakukan penelitian kualitatif. Jakarta: Pustaka Jaya.

Arikunto, S., Suhardjono, \& Supardi. (2010). Penelitian tindakan kelas. Jakarta: Bumi Aksara.

Cohen, L., Manion, L., \& Morrison, K. R. B. (2007). Research methods in education. New York, NY: Routledge.

Creswell, J. W. (2012). Educational research: planning, conducting, and evaluating quantitative and qualitative research. Boston: Pearson.

Creswell, J. W. (2014). Penelitian kualitatif dan desain riset (Memilih diantara lima pendekatan). Yogyakarta: Pustaka Pelajar.

Creswell, J. W. (2016). Research design: pendekatan kualitatif, kuantitatif, dan mixed. Yogyakarta: Pustaka Pelajar.

Denzin, N. K., \& Lincoln, Y. S. (2011). The Sage handbook of qualitative research. 
Jurnal Prima Edukasia, 5 (2), July 2017 - 210

Vina Anggia Nastitie Ariawan, Inne Marthyane Pratiwi

SAGE Publications.

Jadal MM. (2012). Increasing the achievement of students by using the activity based joyful learning approach. Journal of Arts and Culture, 3(2), 976-9862. Retrieved from

http://www.bioinfo.in/contents.php?id=53

Kohn, A. (2010). Turning children into data: A skeptic's guide to assessment programs. Retrieved August 1, 2017, from http://www.alfiekohn.org/article/turningchildren-data/?print=pdf

Lan, Y.-C., Lo, Y.-L., \& Hsu, Y.-S. (2014). The effects of meta-cognitive instruction on students' reading comprehension in computerized reading contexts: A quantitative meta-analysis. Journal of Educational Technology \& Society, 17(4), 186-202.

https://doi.org/10.2307/jeductechsoci.17.4 .186

Linane, M. J. (2014). 6 reading comprehension problems \&amp; what to do about it. Retrieved August 1, 2017, from http://www.coolcatteacher.com/6-readingcomprehension-problems/

MacNaughton, G., \& Hughes, P. (2009). Doing action research in early childhood studies: A step by step guide. Open University Press.

Neuman, W. L. (2014). Social research methods: Qualitative and quantitative approaches. Edinburgh: Pearson Education Limited.

Nurlina, I., Hikmah, N., Chamidah, N., Ristanta, A., Ayu W, R. A., Mastingah, R., ... Rusliyanti, N. (2013). Cooperative learning type treasure clue. Retrieved August 1, 2017, from http://kendaraanbelajar.blogspot.co.id/201 3/06/cooperative-learning-type-treasureclue.html

Ortlieb, E. (2013). Using anticipatory reading guides to improve elementary students' comprehension. International Journal of Instruction July, 6(2), 1694-609. Retrieved from http://www.e- iji.net/dosyalar/iji_2013_2_10.pdf

Proity, S. H. (2015). Effect of joyful teaching on grade IV students" academic performance in science. International Journal of Science and Research (IJSR) ISSN (Online Index Copernicus Value Impact Factor, 4(10), 1232-1240. Retrieved from https://www.ijsr.net/archive/v4i10/SUB15 8946.pdf

Putra, N., \& Dwilestari, N. (2012). Penelitian kualitatif PAUD (Pendidikan Anak Usia Dini). Jakarta: Rajawali Pers.

Rofikasari, F. (2016). Peningkatan keterampilan membaca pemahaman melalui strategi directed reading thinking activity (DRTA) pada siswa kelas $\mathrm{V}$ Sd Negeri 2 Jlegiwinangun tahun ajaran 2014/2015. KALAM CENDEKIA PGSD KEBUMEN, 4(1.1). Retrieved from http://jurnal.fkip.uns.ac.id/index.php/pgsd kebumen/article/view/6751

Sanjaya, W. (2016). Penelitian tindakan kelas. Jakarta: Prenada Media Group.

Shirah, C. L. (2006). Autoethnographical inquiry into joyful teaching: explorations with national teachers of the year. the Jack N. Averitt College of Graduate Studies (COGS). Retrieved from http://digitalcommons.georgiasouthern.ed u/etd

Wei, C.-W., Lee, L., \& Chen, N.-S. (2011). A joyful classroom learning system with robot learning companion for children to learn mathematics multiplication. TOJET: The Turkish Online Journal of Educational Technology, 10(2), 11-23. Retrieved from http://www.tojet.net/articles/v10i2/1022.p df

Zare, P., \& Othman, M. (2013). The relationship between reading comprehension and reading strategy use among Malaysian ESL learners. International Journal of Humanities and Social Science, 3(13), 187-192. Retrieved from http://www.ijhssnet.com/journals/Vol_3_ No_13_July_2013/22.pdf 